\section{Estimation of creatine in red cells}

\section{W. J. GRIFFITHS From the Department of Haematology, Louis Jenner Laboratories, St. Thomas's Hospital and Medical School, London}

Because there is a considerable decline in the creatine of the human red cells with increasing age, the creatine in a mixed population of cells is a sensitive index of their mean age and therefore of marrow erythropoietic activity. In this respect the red cell creatine is superior to a count of the relatively shortlived reticulocytes (Griffiths and Fitzpatrick, 1967).

The usefulness of creatine for the above purpose is obviously dependent upon the ease with which it can be estimated, and where the necessary facilities are available the automated method of Griffiths (1964) is satisfactory. It is the purpose of this paper to describe, as an alternative, a simple manual procedure, which is a modification of that used by Kurohara (1965) and for which $0.2 \mathrm{ml}$ of packed red cells is sufficient.

\section{REAGENTS}

STOCK ALKALI $\mathrm{NaOH}(60 \mathrm{~g})$ and anhydrous $\mathrm{Na}_{2} \mathrm{Co}_{3}$ $(160 \mathrm{~g})$ are dissolved in 1 litre of water. This reagent should be kept in a warm place in winter.

1-NAPHTHOL A $1 \% \mathrm{w} / \mathrm{v}$ solution of 1-naphthol AR in the stock alkali is prepared immediately before use and filtered. It should have no more than a faint straw colour and can be used for at least two hours after preparation if shielded from strong light.

DIACETYL A $1 \% \mathrm{v} / \mathrm{v}$ solution of diacetyl in water is kept at $4{ }^{\circ} \mathrm{C}$ and diluted to $0.05 \%$ with water immediately before use.

NA-P-CHLOROMERCURIBENZOATE To $1.8 \mathrm{~g}$ of $p$-chloromercuribenzoic acid in a $100 \mathrm{ml}$ volmetric flask is added $10 \mathrm{ml}$ of $\mathrm{N}-\mathrm{NaOH}$ and the mixture allowed to stand for about 30 minutes with frequent vigorous shaking. It is diluted with more water, a little at a time, and when solution is complete made up to the mark and filtered. Alternatively, $1.9 \mathrm{~g}$ of Na-p-chloromercuribenzoate ${ }^{1}$ is dissolved in $100 \mathrm{ml} 0 \cdot 1 \mathrm{~N}-\mathrm{NaOH}$.

\section{ZINC SULPHATE, $7 \mathrm{H}_{2} \mathrm{O} 5 \% \mathrm{~W} / \mathrm{V}$ IN WATER}

BARYTA $\mathrm{Ba}(\mathrm{OH})_{2}, 8 \mathrm{H}_{2} \mathrm{O}$ AR (approx. $25 \mathrm{~g}$ ) is added to $500 \mathrm{ml}$ of water in a well-stoppered bottle and shaken from time to time until dissolved. The solution is allowed to stand overnight when the clear supernatant fluid is decanted into another bottle.

${ }^{1}$ Obtained from the Koch-Light Laboratories, Colnbrook, Bucks. Received for publication 14 September 1967.
This solution must be standardized against the $\mathrm{ZnSO}_{4}$ 음 as follows:- Measure $10 \mathrm{ml}$ of the $\mathrm{ZnSO}_{4}$ into a flask, $\frac{\bar{D}}{\partial}$ dilute with $50 \mathrm{ml}$ of water, add a drop of phenolphthalein $\overparen{\mathrm{D}}$ indicator and run in the baryta slowly from a burette until a definite pink colour, which persists for one minute, is obtained. From the quantity of baryta used, which $\vec{\circ}$ should be equal to or less than $10 \mathrm{ml}$, the amount of water to be added to the baryta to make the solutions $\vec{\omega}$ exactly equivalent is calculated. The baryta must be stored in a tightly stoppered bottle (Somogyi, 1945).

STANDARD CREATINE SOLUTIONS Creatine monohydrate $(114 \mathrm{mg})$ is dissolved in $100 \mathrm{ml}$ of water; this stock solution contains $1 \mathrm{mg}$ of creatine per $\mathrm{ml}$ and may be $\vec{N}$ preserved at $4^{\circ} \mathrm{C}$ in a polythene bottle for two to three o weeks. The dilute working standard is prepared by diluting $1 \mathrm{ml}$ of the stock solution to $100 \mathrm{ml}$ with water.

\section{METHOD}

Red cells from heparinized or defibrinated blood may be used; washing is unnecessary. To $0.8 \mathrm{ml}$ of water is added $0.2 \mathrm{ml}$ of the well packed red cells; $3 \mathrm{ml}$ of baryta and $3 \mathrm{ml}$ of $\mathrm{ZnSO}_{4}$ are added, shaking after each addition. After standing for 10 minutes the mixture is centrifuged.

To $4 \mathrm{ml}$ of the clear supernatant fluid is added $0.5 \mathrm{ml}$ of $p$-chloromercuribenzoate, $1 \mathrm{ml}$ of 1-naphthol reagent, $\mathbb{D}$ and $0.5 \mathrm{ml}$ of diacetyl $(0.05 \%)$; shake after each addition. Water, $4 \mathrm{ml}$, is similarly treated as a reagent blank. If a slight turbidity results on addition of the p-chloromercuribenzoate this will subsequently clear.

Three creatine standards are prepared, corresponding to 10,20 , and $40 \mu \mathrm{g}$ of creatine. The dilute working standards, 1,2 , and $4 \mathrm{ml}$ quantities, are made up to $4 \mathrm{ml}$. with water and the reagents added as described above; although not essential the $p$-chloromercuribenzoate is included. Since the colour produced by these standards $O$ obeys Beer's Law, for routine purposes one standard of $₹$ $20 \mu \mathrm{g}$ will suffice; the optical density (OD) of this 은 standard is approximately $\mathbf{0 . 3 2}$.

The test solutions and standards are allowed to stand $\frac{7}{0}$ in the dark for 20 minutes before reading against the reagent blank in $1 \mathrm{~cm}$ cuvettes at $520 \mathrm{~m} \mu$.

CALCULATION mg creatine $\%$ in cells $=\mu \mathrm{g}$ creatine in standard $\times \frac{T}{\mathrm{~S}} \times 0.875$ where $T=O D$ of test; and $\underset{\sigma}{\sigma}$ $\mathrm{S}=\mathrm{OD}$ of standard.

\section{RESULTS AND COMMENTS}

Samples of red cells were estimated both by the manualo method described and the automated technique of Griffiths (1964); the results are shown in Figure 1. It will be seen that there was a close correlation between the results by the two methods. 


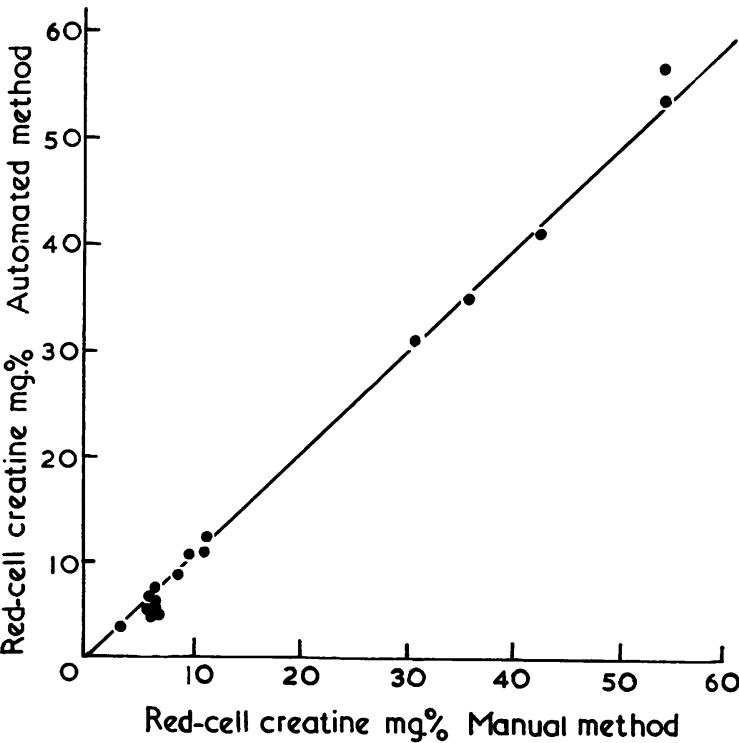

FIG. 1. Red-cell creatine by the present method versus automated method. The line represents equal values by both methods.

The recovery of creatine added to red cells was determined by the manual method. In 15 experiments creatine was added to red cells: this could only be done by adding creatine to the water into which the cells were delivered before deproteinization. When 5 to $50 \mathrm{mg} \%$ of creatine was added to red cells in this way, $83 \%$ to $93 \%$ of the added creatine was recovered.

The observation of Ennor and Stocken (1948) that in the case of biological material containing thiol groups the colour reaction between creatine and diacetyl-1naphthol is partially inhibited was confirmed in the case of red cells; this inhibitory effect may be as much as $20 \%$ and is abolished by the use of $p$-chloromercuribenzoate.

Red cell creatine in normal females was found by Griffiths and Fitzpatrick (1967) to have a mean value of $5.6(\mathrm{SD} \pm 1.3) \mathrm{mg} \%$ and in normal males $4.4(\mathrm{SD} \pm 1.5)$ $\mathrm{mg} \%$. These mean values are in agreement with those of Kurohara (1965), but in each group the spread is much greater than reported by this worker.

The higher values for normal females were found to be statistically significant. It is of interest that Hunter and Campbell (1918), in what is probably the earliest and, until recently, almost the only work on red cell creatine, also found this sex difference.

In subjects exhibiting increased erythropoiesis, such as those responding to treatment for anaemia, values for red cell creatine up to $50 \mathrm{mg} \%$ may be found.

I am grateful to Miss E. J. Lothian for technical assistance. This study was partly supported by the Endowment Fund of St. Thomas's Hospital.

\section{REFERENCES}

Ennor, A. H., and Stocken, L. A. (1948). Biochem. J., 42, 557.

\section{Method for obtaining both frozen and paraffin sections from the same liver biopsy}

S. RAIA AND P. J. SCHEUER From the Departments of Pathology and Medicine, The Royal Free Hospital, London

Liver biopsy is now an established diagnostic technique (Sherlock, 1962). Tissue obtained by this method also provides valuable specimens for histochemical investigation. For diagnostic purposes formalin-fixed, paraffinembedded material is commonly used, whereas many histochemical techniques, especially those demonstrating enzyme activities, require fixed or unfixed frozen sections. The division of a small needle biopsy specimen into two or more parts, however, accentuates the already critical problem of sampling and raises ethical problems because subtracting from the material to be embedded in paraffin may hinder the patient's diagnosis. It was therefore thought necessary to develop a technique for obtaining both frozen and paraffin sections from the total specimen.

\section{MATERIAL}

Eighty-five neec le biopsies and 13 operative wedge biopsies of liver were studied. The patients suffered from a wide range of hepatic and non-hepatic diseases, and eight of the livers were normal.

METHOD

Depending on the histochemical requirements, the specimen, shortly after removal from the patient and preferably at the patient's bedside, is placed in an appropriate fixative or rapidly frozen as follows. The whole needle specimen, or a slice of a wedge biopsy 0.2 to $0.3 \mathrm{~cm}$ thick, is placed on a moistened $0.4 \mathrm{~cm}$ thick piece of $8 \%$ gelatin approximately $1 \mathrm{~cm}$ across. This in turn is placed on a piece of wet cork of similar thickness and slightly larger than the gelatin. The cork provides a convenient base for handling the specimen and for storage. A few drops of water are now put on a metal microtome chuck, and cork, gelatin, and specimen are placed on top of the water. The chuck is grasped with tongs and immersed, together with the specimen, in a hexane-dry ice mixture (Fig. 1). When the specimen is

Rezeived for publication 20 July 1967.

Estimation of creatine in red cells-continued

Griffiths, W. J. (1964). Clin. chim. Acta, 9, 210.

- and Fitzpatrick, M. (1967). Brit. J. Haemat., 13, 175.

Hunter, A., and Campbell, W. R. (1918). J. biol. Chem., 33, 169.

Kurohara, S. S. (1965). Acta radiol. (Stockh.), suppl. 244.

Somogyi, M. (1945). J. biol. Chem., 160,69. 